\title{
PERAN GREEN TRUST DAN GREEN SATISFACTION MEMEDIASI HUBUNGAN GREEN IMAGE DENGAN GREEN LOYALTY
}

\author{
Ni Luh Gde Sari Dewi Astuti ${ }^{1}$ \\ I Putu Gde Sukaatmadja ${ }^{2}$
}

\author{
${ }^{1}$ Fakultas Ekonomi dan Bisnis Universitas Udayana Bali, Indonesia \\ 1e-mail: niluhgdesaridewiastuti@yahoo.co.id \\ ${ }^{2}$ Fakultas Ekonomi dan Bisnis Universitas Udayana Bali, Indonesia
}

\begin{abstract}
ABSTRAK
Green hotel sudah menjadi branding serta strategi dalam memenangkan persaingan bisnis, jika menggunakan energi ramah lingkungan, maka penyelamatan lingkungan bisa jauh lebih baik. Penelitian ini bertujuan untuk menjelaskan hubungan green image dengan green trust, green image dengan green satisfaction, greentrust dengan green loyalty, green satisfaction dengan green loyalty, green image dengan green loyalty, serta untuk menjelaskan peran green trust dan green satisfaction dalam memediasi hubungan green image dengan green loyalty, populasi dalam penelitian ini adalah tamu yang telah menginap di Hotel Bali Tropic Resort \& Spa (minimal sudah pernah menginap 2 kali dalam periode tahun 2013-2017) dengan ukuran sampel sebanyak 100 responden. Penelitian ini menggunakan teknik analisis PLS (Partial Least Square). Penelitian ini menemukan bahwa green image memiliki hubungan positif dengan green trust, green satisfaction, serta green loyalty. Green trust dan green satisfaction memiliki hubungan positif dengan green loyalty. Green trust dan green satisfaction mampu memediasi secara parsial serta memiliki hubungan positif dengan green loyalty.
\end{abstract}

Kata kunci: green marketing, green image, green trust, green satisfaction, green loyalty dan green hotel.

\begin{abstract}
Green hotel has become a branding and strategy in winning business competition, if using environmentally friendly energy. This study aims to explain the relationship green image with green trust, green image with green satisfaction, green trust with green loyalty, green satisfaction with green loyalty, green image with green loyalty, and to explain the role of green trust and green satisfaction in mediating green image relationship with green loyalty. The population in this study are the guests who have been staying at Hotel Bali Tropic Resort \& Spa (minimum 2 times stay in the period of 2013-2017) with sample size of 100 respondents. This research uses analysis technique PLS (Partial Least Square). This study found that green image has a positive relationship with green trust, green satisfaction, and green loyalty. Green trust and green satisfaction have a positive relationship with green loyalty. Green trust and green satisfaction are able to mediate partially and have a positive relationship with green loyalty.
\end{abstract}

Keywords:green marketing, green image, green trust, green satisfaction, green loyalty dan green hotel. 
N.L.G. Sari Dewi Astuti, dan I Pt. Gede Sukaatmadja. Peran Green Trust dan Green .......

\section{PENDAHULUAN}

Kondisi lingkungan sekitar harus dijaga serta dilestarikan dengan baik. Kesadaran dalam diri untuk berkomitmen tinggi dalam melestarikan lingkungan merupakan faktor penting. Mengingat masalah lingkungan yang mengganggu dunia (misalnya pemanasan global, kerusakan lingkungan, kerusakan habitat, polusi udara dan air dan penipisan sumber daya), para konsumen mempertimbangkan pilihan green untuk melakukan hal yang baik bagi bumi. Aspek lingkungan dalam dunia bisnis saat ini merupakan factor terpenting yang harus diperhitungkan dalam melakukan kegiatan pemasaran. Menanggapi masalah lingkungan, perusahaan harus mengembangkan strategi baru yang dapat menjamin pelestarian lingkungan, contohnya seperti green marketing (Chen, 2010; Kang dan Hur, 2012). Chan (2013a) menyatakan bahwa green marketing menjadi salah satu konsep yang paling relevan, dapat disimpulkan bahwa green marketing merupakan konsep pemasaran dengan label "green product" atau produk yang ramah terhadap lingkungan dengan menggabungkan beberapa kegiatan seperti modifikasi produk, perubahan proses produksi, kemasan, strategi iklan dan juga meningkatkan kesadaran pada pemasaran yang ramah terhadap lingkungan. Perubahan perilaku terhadap lingkungan sangat diminati karena dapat menyebabkan perubahan besar yang berpotensi bagi seluruh industri hotel seiring dengan perkembangan waktu beberapa industri perhotelan mulai mengembangkan strategi green marketing untuk memenuhi permintaan para konsumen yang sadar terhadap lingkungan (Hsieh, 2012; Chan, 2013a).

Banyak hotel menggunakan label "green hotel" sebagai strategi untuk 
menarik perhatian pelanggan mereka. Hotel yang ramah lingkungan melakukan program seperti penghematan air, energi dan mengurangi limbah padat yang dapat membantu melindungi bumi. Dampak lingkungan yang dihasilkan perusahaan hotel berkaitan dengan air, energi, serta pembuangan limbah dapat mengakibatkan pada pencemaran tanah, air dan udara Pihak manajemen hotel dalam menerapkan konsep green pada perusahaannya harus bertujuan untuk mengurangi penggunaan energi, mengurangi pencemaran air, pencemaran udara, pencemaran limbah padat serta dapat menggunakan sumber daya secara efisien.

Tidak hanya pelaku bisnis hotel yang harus bertanggung jawab atas dampak dilingkungan sekitarnya, implementasi green initiatives yang efisien harus diikuti dengan komitmen dan dukungan dari para tamu. Liu et al, 2012 menyatakan bahwa keputusan pelanggan dalam membeli atau tidaknya suatu green products akan memiliki pengaruh yang kuat dalam melaksanakan green practices.Seiring dengan perkembangan, masih banyaknya pelanggan atau konsumen yang bersedia menginap dan mencari green hotelsaat ini sektor green hotel merupakan segmen pasar yang sedang naik daun, bukan hanya karena karateristik dari green hotel yang lebih ramah lingkungan saja tetapi green hotel juga dapat membedakan dirinya dari para pesaingnya sehingga dapat memuaskan kebutuhan pasar. Penelitian terdahulu telah meneliti aspek kepercayaan pelanggan, kepuasan, citra dan loyalitas pelanggan yang relevan, dan isu-isu ini belum dibahas dari perspektif green marketing. Berdasarkan kerangka the hierarchy of effects model dua variabel afektif yaitu variable green trust dan green satisfaction, memediasi hubungan antara green overall image dengan green 
N.L.G. Sari Dewi Astuti, dan I Pt. Gede Sukaatmadja. Peran Green Trust dan Green .......

loyalty (Lavidge dan Steiner dalam Martinez, 2015). Memperluas penelitian terdahulu mengenai loyalitas pelanggan dalam konteks green, penelitian ini meneliti strategi green marketing dalam konteks hotel untuk meningkatkan green loyalty dari pelanggan. Perusahaan khususnya hotel melakukan berbagai upaya dalam meningkatkan brand image, bukan hanya untuk menghindari protes karena masalah lingkungan atau hukuman namun juga dapat untuk meningkatkan kepuasan konsumen akan environmental desires, sustainable expectation, dan green needs.

Green brand image merupakan persepsi sebuah merek yangada padabenak konsumen yang berkaitan dengan hal yang menggabungkan antara komitmen dengan kepedulian terhadap lingkungan (Chen 2009). Green satisfaction adalah kepuasan yang terasa ketika salah satu keinginan, kebutuhan atau harapan tentang perlunya produ kramah lingkungan telah terpenuhi (Saleem, 2015). Kepercayaan mengacu pada keyakinan individu bahwa konsumen akan berperilaku berdasarkan harapannya. Green trust ialah dorongan bagi konsumen untuk memiliki kepercayaan pada produk yang memiliki klaim ramah lingkungan (Chen, 2015). Kecenderungan pelanggan untuk percaya bahwa merek tetap pada janjinya mengenai kinerja hijau (green performance). Green loyalty dimana pelanggan ingin mempertahankan hubungan dengan sebuah institusi yang melibatkan masalah lingkungan atau hijau, memiliki komitmen untuk membeli lagi pilihan produk yang digemari dengan konsisten di masa yang akan datang.

Tingginya tingkat kesadaran wisatawan dunia terhadap pelestarian lingkungan menempatkan green hotel atau hotel yang ramah lingkungan sebagai 
pilihan dan kebutuhan. Green hotel sudah menjadi branding serta strategi dalam memenangkan persaingan bisnis, sehingga bila para pengelola hotel tidak menerapkan prinsip-prinsip ramah lingkungan tentunya akan ditinggalkan tamu, dengan menggunakan energi ramah lingkungan, maka penyelamatan lingkungan bisa jauh lebih baik. Penelitian ini dilakukan di Bali Tropic Resort \& Spa. Bali Tropic Resort \& Spa memiliki berbagai macam fasilitas dan aktivitas yang ditawarkan kepada pengunjungnya. Hotel ini termasuk 10 (sepuluh) hotel terbaik di Indonesia yang mendapatkan green hotel award yang diselenggarakan oleh Deputi Bidang Pengembangan Destinasi dan Industri Pariwisata pada tahun 2015 lalu. Penelitian ini bertujuan untuk menjelaskan hubungan green image terhadap green trust, green image terhadap green satisfaction, green trust terhadap green loyalty, green satisfaction terhadap green loyalty, green image terhadap green loyalty, serta untuk menjelaskan peran green trust dan green satisfaction dalam memediasi hubungan green image dengan green loyalty.

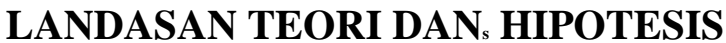

\section{1) Greens Marketing}

Asal usul konsep "green marketing” terletak pada dekade tahun delapan puluhan (Chen, 2010). Kesempatan untuk mengembangkan keuntungan dari citra dan reputasi perusahaan (Lee et al, 2010) kesempatan untuk mencariipasar baruudannmeningkatkan nilai produk (Chen, 2010). Penelitian yang ada mengenai isu green marketing berfokus pada memproduksi produk manufaktur seperti kosmetik, perlengkapan, mobil hibrida,produk elektronik (Chen, 2010; Hur et al, 2013; Ng et al, 2014). Berdasarkan hierarchy of effects theory untuk 
N.L.G. Sari Dewi Astuti, dan I Pt. Gede Sukaatmadja. Peran Green Trust dan Green .......

mengeksplorasi bagaimana konsekuensi overall image dalam green hotel (misalnya green trust dan green satisfaction) dapat mempengaruhi kesetiaan hijau. Chan (2013) menyatakan penelitian tentang green marketing di industri hotel yang dipandang kurang sensitif.

\section{2) Green Image}

Wisatawan cenderung memilih destinasi wisata dengan citra yang bagus. Industri perhotelan mendukung hubungan antara overall image dan green behavioral intentions terhadap worth of mouth, niat berkunjung dan kesiapan untuk membayar harga yang lebih tinggi. Menurut hierarchy of effects theory, tahap perilaku afektif dari seorang pelanggan dimulai dengan membangkitkan perasaan berdasarkan persepsi perusahaan (Lavidge dan Steiner dalam Martinez, 2015). Mengikuti pendekatan ini, green overall image merupakan seperangkat keyakinan yang menentukan citra suatu perusahaan. Chen (2010) juga mengartikan green brand image sebagai persepsi yang timbul di dalam benak konsumen terhadap suatu merek tertentuu yangg memiliki komitmen dan kepeduliannya terhadap kelestarian lingkungan.

\section{3) Green Trust}

Kepercayaan adalah suatu keinginan untuk bergantung pada pihak lain berdasarkan harapan-harapan yang terbentuk sebagai hasil dari kemampuan, kejujuran dan niat baik pihak lain itu. Green trust ialah kepercayaan pada sebuah produk, jasa atau merek yang dihasilkan dari kredibilitas, kebaikan dan kemampuan produk atau jasa tersebut berdasarkan kepedulian terhadap lingkungan sekitar (Ganesan dalam Martinez, 2015). 


\section{4) Green Satisfaction}

Green satisfaction di mana konsumen merasa puas ataupun senang terhadap produk yang dipilih karena dapat memenuhi kebutuhan, hasrat, dan keinginan konsumen dalam kepedulian mereka terhadap lingkungan (green needs) dan pemenuhan ini bersifat menyenangkan bagi konsumen (Bansal dan Barnet dalam Chang dan Fong, 2010). Green satisfaction merupakan kepuasan dan kebahagiaan konsumen karena produkyang ramah lingkungan yang telah dikonsumsi sesuai dengan harapan, keinginan dan kebutuhan mereka.

\section{5) Green Loyalty}

Loyalitas pelanggan telah menjadi tujuan strategis bagi perusahaan dan hal ini sangat penting bagi perusahaan khususnya di sektor jasa, mengingat bahwa pelanggan memandang risiko yang lebih besar dalam memilih pelayanan (Polo et $a l$, 2013). Selain itu, loyalitas pelanggan merupakan ambisi akhir dari sejumlah perusahaan, pelanggan yang setia membeli lebih banyak, mereka dapat menghabiskan sebagian besar dari pendapatan mereka untuk membeli sesuatu dan cenderung tidak terlalu memperdulikan harga dibandingkan pelanggan lain (Williams dan Naumann, 2011). Frekuensi kunjungan dari konsumen loyal lebih tinggi jika dibandingkan dengan konsumen non-loyal, konsumen loyal berani membeli lebih dari konsumen non-loyal. Selain itu, mereka mungkin tidak mempertimbangkan brand dari hotel pesaing, mereka memutuskan memilih akomodasi berdasarkan alasan ekonomi (Yoo dan Bai, 2013). 
N.L.G. Sari Dewi Astuti, dan I Pt. Gede Sukaatmadja. Peran Green Trust dan Green .......

\section{6) The Hierarchy Model Effects}

Menganggap bahwa pelanggan biasanya tidak beralih dari individu yang tidak tertarik untuk melakukan pembelian secara langsung dalam satu langkah seketika Lavidge dan Steiner (1961) dalam Martinez (2015). Sebagai gantinya, pelanggan mendekati pembelian melalui proses multi tahap, dimana pembelian itu sendiri adalah langkah terakhir. Sebaliknya, pelanggan mendekati pembelian melalui multi - tahap proses, yang pembelian itu sendiri adalah langkah terakhir. Lavidge dan Steiner (1961) dalam Martinez (2015), membagi tahapan perilaku pelanggan menjadi tiga komponen:

a) Dimensi kognitif (atau rasional), yang mengacu pada pikiran dan keyakinan pelanggan;

b) Dimensi afektif (atau emosional), mengacu pada ranah emosi; dan

c) Dimensi konatif (atau motivasi), mengacu kepada pelanggan niat perilaku dan tindakan.

Dalam urutan kognitif - afektif - konatif ini, green overall image adalah seperangkat keyakinan yang menentukan citra perusahaan. Secara berurutan, kepercayaan ini menentukan respons afektif dari pelanggan (green trust dan green satisfaction). Kognitif mengevaluasi perusahaan berhubungan dengan biaya untuk menjadi pelanggannya. Akhirnya, respons afektif ini mempengaruhi hasil konseptual perilaku pelanggan, seperti perilaku rekomendasi dan pembelian kembali (green loyalty). 


\section{Hipotesis Penelitian}

\section{1) HubunganGreen Image dengan Green Trust}

Penelitian terdahulu menunjukkan adanya hubungan postif antara green brand image (citra merek hijau) dengan green trust (kepercayaan hijau) pada produk elektronik di Taiwan (Chen 2010). Semakin kuat citra merek hijau atau green brand image maka semakin tinggi pula keinginan konsumen untuk sepenuhnya percaya melalui kemampuan dan kredibilitas merek tersebut tentang image produk yang mengedepankan kelestarian lingkungannya. Hasil penelitian Efendy (2014) menyatakan bahwa brand image memiliki pengaruh yang positif dan signifikanterhadap brand trust di Restoran D'Cost Surabaya. Peneltian selanjutnya yang dilakukan oleh Wiyono (2015) dimana terdapat hubungan positif dan signifikan antara green brand image dengan green trust pada merek LG di Surabaya. Hasil penelitian dari Astini (2016) menyatakan bahwa green brand image memiliki pengaruh yang negatif terhadap green trust pada produk AMDK galon merek AQUA. Siwandana (2017), menyatakan bahwa green brand image memiliki pengaruh signifikan dan positif terhadap green trust pada produk Bali Tangi. Berdasarkan hasil-hasil studi empiris tersebut, penelitian ini merumuskan hipotesis 1 sebagai berikut:

$\mathrm{H}_{1}$ : Green image memiliki hubungan positif dengan green trust

\section{2) Hubungan Green Image dengan Green Satisfaction}

Pianroj (2012) menyatakan bahwa green image berhubungan positif dengan green satisfaction pada green hotel di Thailand Selatan.Penelitian lain mendukung bahwa green brand image berpengaruh positif dan signifikan pada 
N.L.G. Sari Dewi Astuti, dan I Pt. Gede Sukaatmadja. Peran Green Trust dan Green .......

green satisfaction studi pada pengguna produk hijau di Surakarta oleh Waluyo (2013). Wiyono (2015) di mana terdapat hubungan positif dan signifikan antara green brand image dengan green satisfaction padamerek LG di Surabaya. Penelitian Wenur et al. (2015) menyatakan citra merek hijau (green brand image) secara parsial berpengaruh tidak signifikan terhadap kepuasan konsumen hijau (green satisfaction) pada produk The Body Shop di ManadoTownSquare. Hasil peneltian terdahulu menyatakan bahwa green brand mage memiliki pengaruh yang signifikan terhadap green satisfaction padaproduk AMDKgalon AQUAdapat memberikan dampak kepuasan (green satisfaction) dari sisi konsumen (Astini 2016). Berdasarkan studi empiris tersebut, penelitian ini merumuskan hipotesis 2 sebagai berikut:

$\mathrm{H}_{2}$ : Green image memiliki hubungan positif dengan green satisfaction

\section{3) Hubungan GreenTrust dengan Green Loyalty}

Ouyang (2010) juga menjelaskan bahwa kepercayaan konsumen memiliki hubungan positif dengan loyalitas konsumen. Hasil penelitian terdahulu yang dilakukan oleh Yi Kuo (2012) menyatakan bahwa tidak mendukung brand trust terhadap brand loyalty pada konsumen penggunaan ponsel dan laptop. Hasil penelitian dari Raza dan Rehman (2012) menyatakan kepercayaan yang dimiliki oleh pelanggan mempunyai pengaruh yang kuat untuk membentuk loyalitas. Hayu (2014) menyatakan green trust memiliki pengaruh yang positif dan signifikan terhadap loyalitas konsumen produk lampu hemat energi. Hasil penelitian Efendy (2014) menyatakan brand trust memiliki pengaruh yang positif dan signifikan terhadap brand loyalty di Restoran D'Cost Surabaya. Penelitian yang dilakukan 
oleh Nirmalasari dan Sukma (2015) menunjukan bahwa trust berpengaruh positif terhadap customer loyalty di klinik perawatan dan kecantikan Be-Hati. Kepercayaan yang dimiliki konsumen produk ADMK gallon AQUA berdampak positif pada keloyalitasan konsumen produk AMDK galon merek AQUA (Astini, 2016). Berdasarkan hasil-hasil studi empiris tersebut, penelitian ini merumuskan hipotesis 3 sebagai berikut:

$\mathrm{H}_{3}$ : Green trust memiliki hubungan positif dengan green loyalty

\section{4) Hubungan Green Satisfaction dengan Green Loyalty}

Muji (2008) menyatakan kepuasan konsumen tidak berpengaruh signifikan terhadap loyalitas konsumen kartu kredit jenis visa pada BNI'46 Graha Pangeran Surabaya. Hasil penelitian Ramadhan (2010) menyatakan bahwa green satisfaction secara positif berhubungan dengan customer loyalty. Pianroj (2012) menyatakan bahwa green satisfaction berhubungan positif dengan green loyalty pada green hotel Thailand Selatan.Hayu (2014) menyatakan bahwa kepuasan berpengaruh terhadap loyalitas konsumen namun tidak signifikan. Nirmalasari dan Sukma (2015) menyatakan bahwa bahwa satisfaction berpengaruh signifikan positif pada customer loyalty di klinik perawatan dan kecantikan Be-Hati. Berdasarkan hasil-hasil studi empiris tersebut, penelitian ini merumuskan hipotesis 4 sebagai berikut:

$\mathrm{H}_{4}$ : Green satisfaction memiliki hubungan positif dengan green loyalty

\section{5) Hubungan Green Image dengan Green Loyalty}

Penelitian terdahulu telah dilakukan oleh Chang dan Fong (2010) yang menyatakan bahwa green corporate image berhubungan positif terhadap green 
N.L.G. Sari Dewi Astuti, dan I Pt. Gede Sukaatmadja. Peran Green Trust dan Green .......

loyalty. Penelitian Yi Kuo (2012) menemukan hal yang berbeda bahwa pengaruh green image terhadap green loyalty pada konsumen penggunaan ponsel dan laptop tidak berpengaruh. Penelitian Susanti (2014) menyatakan citra merek berpengaruh signifikan terhadap loyalitas pelanggan pada produk kosmetik hijau merek The Body Shop. Bastian (2014) menyatakan bahwa brand image berpengaruh positif signifikan terhadap brand loyalty studi pada PT Ades Alfindo Putra Setia. Efendy (2014) menyatakan bahwa brand image mempunyai pengaruh yang positif dan signifikan terhadap brand loyalty di Restoran D'Cost Surabaya. Berdasarkan hasil-hasil studi empiris tersebut, penelitian ini merumuskan hipotesis 5 sebagai berikut:

$\mathrm{H}_{5}$ : Green image memiliki hubungan positif dengan green loyalty.

\section{6) Peran Green Trust Dalam Memediasi Hubungan Green Image Dengan Green Loyalty}

Penelitian terdahulu yang dilakukan oleh Yi Kuo (2012), menemukan bahwa brand trust tidak mampu memediasi hubungan antara green brand image terhadap green loyalty pada konsumen penggunaan ponsel dan laptop. Martinez (2015), memberikan bukti empiris bahwa green trust memediasi hubungan antara green image dan green loyalty. Handayani (2015) menyatakan bahwa brand trust sebagai variabel yang memediasi pengaruh brand image terhadap brand loyalty studi pada pemakai motor matic merek Yamaha di kota Semarang. Berdasarkan hasil-hasil studi empiris tersebut, penelitian ini merumuskan hipotesis 6 sebagai berikut:

$\mathrm{H}_{6}$ : Green trust mampu memediasi hubungan green image dengan green loyalty. 


\section{7) Peran Green Satisfaction Dalam Memediasi Hubungan Green Image Dengan Green Loyalty}

Green satisfaction mampu memediasi hubungan antara green image dengan customer loyalty pada green hotel Thailand SelatanPianroj (2012). Pramudyo (2012) menyatakan bahwa kepuasan merupakan sebagai variabel intervening, antara citra merek terhadap loyalitas studi pada mahasiswa perguruan tinggi swasta di Yogyakarta. Penelitian Martinez (2015), memberikan bukti empiris bahwa green satisfaction mampu memediasi hubungan antara green image dengan green loyalty. Hal ini berbeda dengan hasil penelitian dari Maskur (2014) menyatakan bahwa kepuasan pelanggan tidak memediasi citra terhadap loyalitas pelanggan di Pasar Swalayan Carrefour Semarang. Berdasarkan hasil-hasil studi empiris tersebut, penelitian ini merumuskan hipotesis 7 sebagai berikut:

$\mathrm{H}_{7}$ : Green satisfaction mampu memediasi hubungan green image dengan green loyalty.

\section{Gambar1.KerangkaKonseptualPenelitian}

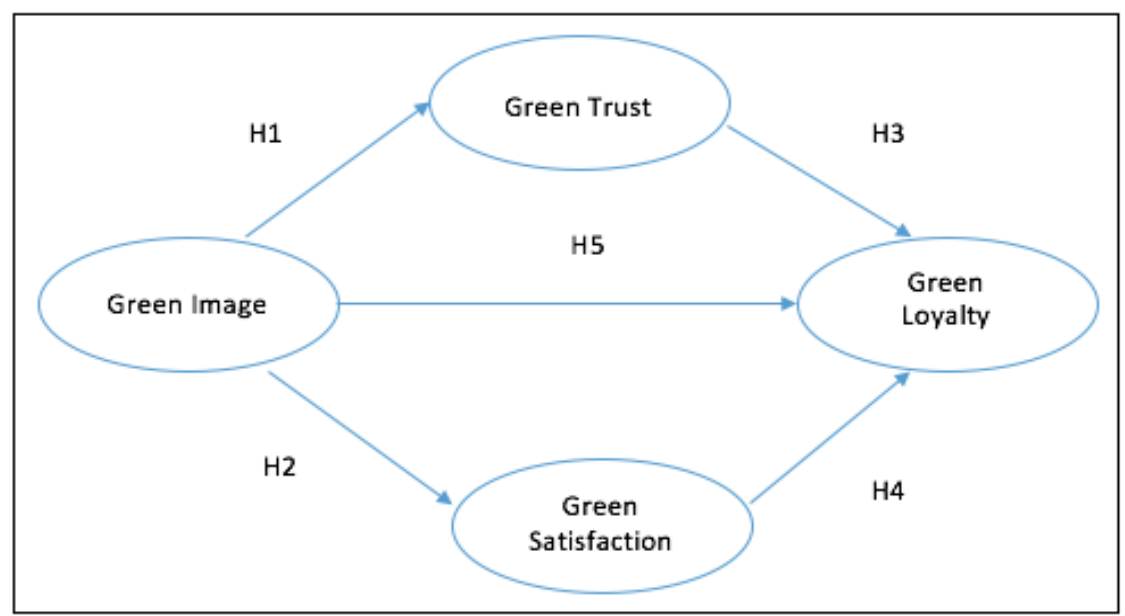


N.L.G. Sari Dewi Astuti, dan I Pt. Gede Sukaatmadja. Peran Green Trust dan Green .......

\section{METODE PENELITIAN}

Tujuan dari penelitian ini adalah eksplanatoris research. Desain penelitian ini menggunakan studi cross-sectional atau studi kasus (one shot). Jenis penelitian dalam penelitian ini adalah kualitatif. Penelitian ini termasuk jenis penelitian kausalitas. Obyek dari penelitian adalah peran green trust dan green satisfaction memediasi hubungan green image dengan green loyalty di Hotel Bali Tropic Resort \& Spa. Di dalam penelitian ini elemen tempat yaitu Hotel Bali Tropic Resort \& Spa, elemen pelaku yaitu tamu dari Hotel Bali Tropic Resort \& Spa, dan elemen aktivitas yaitu tamu yang telah menginap di Hotel Bali Tropic Resort \& Spa (minimal sudah pernah menginap 2 kali dalam periode tahun 2013-2017). Jumlah sampel dalam penelitian ini ialah 100, berdasarkan jumlah sampel yang baik yaitu sebanyak5-10 x jumlah parameter yang diestimasi (Ferdinand, 2006:44). Kriteria disesuaikan dengan penelitian ini menghasilkan rentang (5 10) $\mathrm{x} 17=85$ sampai 170 . Metode pemilihan sampel pada penelitian ini menggunakan metode non probabilitas atau secara acak/ tidak acak elemenelemen populasi tidak mempunyai kesempatan yang sama untuk terpilih menjadi sampel. Teknik non-probabilistic sampling yang digunakan dalam penilitian ini adalah convenience sampling Kuesioner digunakan sebagai metode pengumpulan data. Teknik analisis data menggunakan analisis deskriptif dan Partial Least Square (PLS). 


\section{HASIL DAN PEMBAHASAN}

\section{Karateristik Responden}

Sebanyak 27,0 persen tamu yang menginap di Hotel Bali Tropic Resort \& Spa rata-rata pada usia 35-44 tahun dan 45-54 tahun, sebagian besar dari mereka sudah berkeluarga dan mereka berlibur serta memilih menginap di Hotel Bali Tropic Resort \& Spa bersama keluarganya. Family merupakan salah satu target pasar dari Hotel Bali Tropic Resort \& Spa. Sebanyak 38,0 persen pekerjaan dari tamu yang menginap di Hotel Bali Tropic Resort \& Spa sebagian besar merupakan pekerja, mereka menghabiskan waktu liburan mereka sambil menikmati pantai dan memilih untuk menginap di Hotel Bali Tropic Resort \& Spa dikarenakan lokasi hotel ini cukup dekat dengan pantai. Untuk presentase pemesanan kamar sebanyak 57,0 persen didominasi oleh tamu berjenis kelamin laki-laki. Sebanyak 89,0 persen tamu yang menginap pendidikan tertinggi pada tingkat sarjana.

\section{Analisis Model Penelitian}

\section{a. Evaluasi Model Pengukuran (Outer Model)}

Tahap pertama pada analisis data adalah outer model. Hal ini dilakukan dengan mengukur validitas dan reliabilitas. Pengukuran validitas menggunakan dua indikator ketentuan, yakni menggunakan evaluasi convergent validity dan discriminant validity, sedangkan pengukuran reliabilitas dengan menggunakan cronbachs alpha dan composite reliability. Hasil pengukuran model dapat dilihat pada Tabel 1. 


\section{Pengujian Outer Model}

Tabel 1.

\begin{tabular}{lccc}
\hline \multicolumn{1}{c}{ Variabel } & $\begin{array}{c}\text { Composite } \\
\text { Reliability }\end{array}$ & Cronbach's Alpha & AVE \\
\hline Green image $(\mathrm{X})$ & 0,893 & 0,851 & 0,626 \\
Green trust $\left(\mathrm{Y}_{1}\right)$ & 0,912 & 0,880 & 0,676 \\
Green satisfaction $\left(\mathrm{Y}_{2}\right)$ & 0,892 & 0,820 & 0,734 \\
Green loyalty $\left(\mathrm{Y}_{3}\right)$ & 0,938 & 0,911 & 0,790 \\
\hline
\end{tabular}

Sumber: Data primer, 2017

\section{b. Evaluasi Model Struktural (Inner Model)}

Tahap kedua pada analisis data adalah inner model. Hal ini dilakukan untuk melihat hubungan antara konstruk, nilai signifikansi dan $R$-square dari model penelitian. Selain menggunakan $R$-square, goodness of fit model juga diukur dengan menggunakan $Q$-square predictive relevance, maka rumusnya sebagai berikut:

$$
\begin{aligned}
\mathrm{Q}^{2}= & 1-\left(1-\left(\mathrm{R}_{1}\right)^{2}\right)\left(1-\left(\mathrm{R}_{2}\right)^{2}\right)\left(1-\left(\mathrm{R}_{3}\right)^{2}\right) \\
& =1-\left(1-(0,593)^{2}\right)\left(1-(0,448)^{2}\left(1-(0,711)^{2}\right)\right. \\
& =1-(0,407)(0,552)(0,289) \\
& =1-0,159 \\
& =0,841
\end{aligned}
$$

Besaran $\mathrm{Q}^{2}$ memiliki nilai dengan rentang $0<\mathrm{Q}^{2}<1$, di mana semakin mendekati 1 berarti model semakin baik. Maka dari hasil perhitungan tersebut didapat nilai $\mathrm{Q}^{2}$ adalah sebesar 0,841 , sehingga dapat disimpulkan bahwa model memiliki predictive relevance yang baik $\left(Q^{2}=0,841>0\right)$.

Tabel2.

Pengujian Inner Model

\begin{tabular}{cc}
\hline Konstruk & R-square \\
\hline Green trust $\left(\mathrm{Y}_{1}\right)$ & 0,593 \\
Green satisfaction $\left(\mathrm{Y}_{2}\right)$ & 0,448 \\
Green loyalty $\left(\mathrm{Y}_{3}\right)$ & 0,711 \\
\hline
\end{tabular}

Sumber: Data primer, 2017 


\section{Hasil Pengujian Hipotesis}

Signifikan parameter yang diestimasi memberikan informasi yang sangat berguna mengenai hubungan antara variabel-variabel penelitian. Pengujian hipotesis dilakukan dengan menggunakan $t$-statistics. Apabila nilai $t$-statistics $\geq$ nilai t-tabel $(1,96)$, maka $\mathrm{H}_{\mathrm{o}}$ ditolak dan hipotesis diterima. Berdasarkan pada Tabel 3 dapat dilihat bahwa hipotesis pada penelitian ini diterima.

Tabel 3.

Hasil Tes Hipotesis

\begin{tabular}{lccl}
\hline \multicolumn{1}{c}{ Konstruk } & $\begin{array}{c}\text { Koefisien } \\
\text { Korelasi }\end{array}$ & t Statistics & Keterangan \\
\hline Green image $(\mathrm{X}) \rightarrow$ Green trust $\left(\mathrm{Y}_{1}\right)$ & 0,770 & 15,358 & Signifikan \\
Green image $(\mathrm{X}) \rightarrow$ Green satisfaction & 0,670 & 10,924 & Signifikan \\
$\left(\mathrm{Y}_{2}\right)$ & 0,348 & 3,012 & Signifikan \\
Green trust $\left(\mathrm{Y}_{1}\right) \rightarrow$ Green loyalty $\left(\mathrm{Y}_{3}\right)$ & 0,366 & 4,076 & Signifikan \\
Green satisfaction $\left(\mathrm{Y}_{2}\right) \rightarrow$ Green loyalty & 0,218 & 2,561 & Signifikan \\
$\left(\mathrm{Y}_{3}\right)$ & & &
\end{tabular}

Sumber: Data primer, 2017

Pengujian green trust dan green satisfaction sebagai pemediasi dapat dilihat dari nilai VAF masing-masing variabel pemediasi. Jika nilai VAF di atas 80 persen, maka menunjukkan peran variabel green trust maupun green satisfaction sebagai pemediasi penuh (full mediation). Variabel green trust dan green satisfaction dikategorikan pemediasi parsial apabila nilai VAF berkisar antara 20 persen sampai dengan 80 persen, namun jika nilai VAF kurang dari 20 persen dapat disimpulkan bahwa hampir tidak ada efek mediasi. 
Tabel 4.

Uji Efek Mediasi Green Trust pada Hubungan Green Image dengan Green Loyalty

\begin{tabular}{lc}
\hline $\begin{array}{l}\text { Pengaruh tidak langsung } \mathbf{0 , 7 7 0} * \mathbf{0 , 3 4 8} \\
(\text { Green image } \rightarrow \text { Green trust }=0,770 ; \text { Green } \text { trust } \rightarrow \text { Green loyalty }=0,348)\end{array}$ & 0,267 \\
\hline $\begin{array}{l}\text { Pengaruh langsung sebelum dimasukkan variabel pemediasi } \\
\text { (Green image } \rightarrow \text { Green loyalty }=0,512\end{array}$ & 0,512 \\
PengaruhhTotal & 0,779 \\
VAF = pengaruh tidak langsung/pengaruh total $=0,267 / 0,779$ & $\mathbf{0 , 3 4}$ \\
\hline
\end{tabular}

Sumber: Data diolah, 2017

Tabel 5.

Uji Efek Mediasi Green Satisfaction pada Hubungan Green Image dengan Green Loyalty

\begin{tabular}{lc}
\hline $\begin{array}{l}\text { Pengaruh tidak langsung } \mathbf{0 , 6 7 0} * \mathbf{0 , 3 6 6} \\
\text { (Green image } \rightarrow \text { Green satisfaction }=0,670 ; \text { Green satisfaction } \rightarrow \text { Green loyalty }= \\
0,366)\end{array}$ & 0,245 \\
\hline $\begin{array}{l}\text { Pengaruh langsung sebelum dimasukkan variabel pemediasi } \\
\text { (Green Image } \rightarrow \text { Green Loyalty }=0,512\end{array}$ & 0,512 \\
PengaruhnTotal & 0,757 \\
\hline $\mathrm{VAF}=$ pengaruh tidak langsung/pengaruh total $=0,245 / 0,757$ & $\mathbf{0 , 3 2}$ \\
\hline
\end{tabular}

Sumber: Data diolah, 2017

\section{1) Hubungan green image dengangreen trust}

Green image memiliki hubungan positif dengan green trust. Semakin kuat citra hijau (green image), semakin tinggi pula keinginan konsumen untuk percaya terhadap image dengan memberikan keyakinanatau harapan yang dihasilkan dari kredibilitas, kebajikan, dan kemampuan image tersebut terkait kinerja lingkungannya (Chen,2010). Hotel Bali Tropic Resort \& Spa yang menerapkan strategi green marketing untuk meningkatkan keunggulan bersaing pada produk hijau yang ditawarkan harus memperhatikan persepsi yang tercipta di dalam benak tamu sebagai hotel dengan image ramah lingkungan dan memperkuat kepercayaan tamu melalui pemberian informasi sehubungan dengan pertimbangan lingkungan. Semakin tinggi tingkat kesadaran tamu terhadap lingkungan serta didukung oleh green image yang kuat yang dimiliki oleh Hotel Bali Tropic Resort \& Spa maka semakin tinggi pula keinginan tamu untuk sepenuhnya percaya 
melalui kemampuan dan kredibilitas merek tersebut untuk memilih menginap di Hotel Bali Tropic Resort \& Spa. Hasil penelitian ini mendukung penelitian terdahulu yang dilakukan oleh Chen (2010), Efendy (2014), Wiyono (2015), dan Siwandana (2017). Hasil penelitian ini membantah penelitian dari Astini (2016).

\section{2) Hubungan green image dengan green satisfaction}

Green image memiliki hubungan positif dengan green satisfaction. Citra merek terhadap produk hijau merupakan seperangkat persepsi dari suatu merek dalam benak konsumen yang terkait dengan komitmen dan kepedulian terhadap lingkungan (Chen, 2010). Hal inimenunjukkan bahwa green image yang dimiliki oleh Hotel Bali Tropic Resort \& Spa berdampakpada kepuasan tamu. Semakin tinggi green image yang dimiliki oleh Hotel Bali Tropic Resort \& Spa maka kepuasan yang dirasakan oleh tamu selama mereka menginap di Hotel Bali Tropic Resort \& Spa semakinmeningkat. Hasil penelitian ini mendukung penelitian terdahulu yang dilakukan oleh Chen (2009), Pianroj (2012), Waluyo (2013), Wiyono (2015), dan (Astini 2016). Penelitian ini membantah hasil penelitian yang dilakukan oleh Wenur et al. (2015).

\section{3) Hubungan green trust dengangreen loyalty}

Green trust memiliki hubungan positif dengan green loyalty. Kepercayaan dan komitmen merupakan kunci keberhasilan dari suatu hubungan antar Hotel Bali Tropic Resort \& Spa dengan tamunya. Adanya kesediaan konsumen untuk mempercayai kemampuan sebuah produk atau brand akan mempunyai hubungan yang positif dengan niat melakukan pembelian ulang dan akan melakukan intensitas pembelian ulang yang dapat mempengaruhi loyalitas konsumen. 
N.L.G. Sari Dewi Astuti, dan I Pt. Gede Sukaatmadja. Peran Green Trust dan Green .......

Adanya pengaruh positif ini, menunjukkan bahwa Hotel Bali Tropic Resort \& Spa memiliki green trust yang baik sehingga dapat menimbulkan green loyalty yang baik pula, dengan demikianpenelitian ini mendukung penelitian terdahuluyang dilakukan oleh Ouyang (2010), Raza dan Rehman (2012), Hayu (2014), Efendy (2014), Nirmalasari dan Sukma (2015), dan Astini (2016). Hasil penelitian ini membantah hasil penelitian dari Yi Kuo (2012).

\section{4) Hubungan green satisfactiondengangreen loyalty}

Green satisfaction memiliki hubungan positif dengan green loyalty. Hotel Bali Tropic Resort \& Spa harus mampu untuk meningkatkan kepuasan serta mempertahankan kepuasan tamu tersebut untuk menciptakan loyalitas terhadap suatu produk dan jasa. Adanya kepuasan tersebut maka tamu akan membeli ulang produk tersebut secara konsisten sepanjang waktu, sehingga terciptalah loyalitas konsumen terhadap produk atau merek tersebut. Hasil penelitian ini mendukung penelitian terdahulu yang dilakukan oleh Ramadhan (2010), Pianroj (2012), Hayu (2014), Nirmalasari dan Sukma (2015). Penelitian ini membantah penelitian terdahuluyang dilakukan oleh Muji (2008).

\section{5) Hubungan green imagedengangreen loyalty}

Green image memiliki hubungan positif dengan green loyalty, dengan adanya pengaruh positif ini, menunjukkan bahwa Hotel Bali Tropic Resort \& Spa memiliki green image yang baik dan menimbulkan green loyalty yang baik pula. Hubungan antara green image dengan green loyalty terletak pada keinginankeinginan dan pilihan konsumen (preference) atas suatu image adalah merupakan sikap konsumen. Tamu akan menunjukkan sikap loyalitas mereka ketika tidak 
hanya menginap secara berulang tetapi juga benar-benar menyukai dan memilih menginap di Hotel Bali Tropic Resort \& Spa. Hal ini menunjukkan green image yang dibentuk karena Hotel Bali Tropic Resort \& Spa mampu memberikan presepsi yang baik kepada tamu dan juga menjaga dan mengelola hubungan dengan tamu di Hotel Bali Tropic Resort \& Spa, dengan demikian penelitian ini mendukung penelitian dari Chang dan Fong (2010), Susanti (2014), Bastian (2014), Efendy (2014), penelitian ini membantah temuan penelitian dari Yi Kuo (2012).

\section{6) Peran green trust dalam memediasi hubungan green image dengangreen loyalty}

Perhitungan VAF efek mediasi green trust pada hubungan green image dengan green loyalty adalah sebesar 34 persen dan menunjukkan bahwa green trust mampu memediasi secara parsial. Green trust memberikan hubungan mediasi yang positif terhadaphubungan green image dengan green loyalty, dengan demikian dapat dikatakan bahwa semakin meningkatnya green trust yang disebabkan oleh adanya green image yang positif, maka green loyalty dari tamu juga semakin meningkat. Hasil ini mengandung arti bahwa semakin baik green image yang diciptakan oleh Hotel Bali Tropic Resort \& Spa, maka semakin baik pula kepercayaan di mata tamu. Green trust pada tamu mempunyai pengaruh terhadap loyalitas berupa niat ulang seperti menginap kembali di Hotel Bali Tropic Resort \& Spa. Berdasarkan pada hasil temuan penelitian ini mampu memberikan bukti secara empiris bahwa green trust juga mampu memediasi dan merupakan variabel intervening dan berfungsi memediasi green image dengan 
N.L.G. Sari Dewi Astuti, dan I Pt. Gede Sukaatmadja. Peran Green Trust dan Green .......

green loyalty secara parsial. Penelitian lainnya yang mendukung hasil penelitian ini adalah Martinez (2015) dan Handayani (2015), dengan demikian penelitian ini membantah hasil penelitian dari Yi Kuo (2012).

\section{7) Peran green satisfaction dalam memediasi hubungan green image dengan green loyalty}

Perhitungan VAF efek mediasi green satisfaction pada hubungan green image dengan green loyalty adalah sebesar 32 persen dan menunjukkan green satisfaction mampu memediasi secara parsial. Green satisfaction memberikan hubungan mediasi yang positif terhadap hubungan green image dengan green loyalty, dengan demikian dapat dikatakan bahwa semakin meningkatnya green satisfaction yang disebabkan oleh adanya green image yang positif, maka green loyalty dari tamu juga semakin meningkat. Hasil ini mengandung arti bahwa dengan adanya green image yang baik dari Hotel Bali Tropic Resort \& Spamaka dapat membantu tamu dalam mengambil keputusan untuk memilih dan menginap di Hotel Bali Tropic Resort \& Spa. Karena tamu sudah percaya dengan reputasi baik, tentunya tamu tidak menginap hanya sekali, tetapi berkali-kali. Tujuan dari semua bisnis adalah menciptakan kepuasan konsumen. Kepuasan yang tercipta dari pengalaman menggunakan atau mengkonsumsi produk atau jasa akan memberikan kesetiaan kepada tamu untuk menginap atau merekomendasikan Hotel Bali Tropic Resort \& Spa kepada orang lain. Berdasarkan hasil temuan penelitian ini mampu memberikan bukti secara empiris bahwa green satisfaction merupakan variabel intervening dan berfungsi memediasi green image dengan green loyalty secara parsial. Temuan penelitian ini juga mendukung penelitian 
dari Pramudyo (2012), Pianroj (2012) dan Martinez (2015) dan berhasil membantah penelitian dari Maskur (2014).

\section{IMPLIKASI DAN KETERBATASAN PENELITIAN}

Penelitian ini mengikuti pendekatan holistik dengan menggabungkan dua perspektif, yaitu relationship marketing dan green marketing dengan mengembangkan kerangka penelitian untuk memahami green customer loyalty. Memperluas penelitian terdahulu pada green marketing dan customer loyalty dengan memasukan green trust dan green satisfaction sebagai variabel mediasi. Hasil penelitian ini menunjukkan bahwa green image secara positif tidak hanya mempengaruhi green loyalty tetapi juga mempengaruhi green trust dan green satisfaction di Hotel Bali Tropic Resort \& Spa. Penelitian ini memberikan bukti empiris bahwa green trust dan green satisfaction mampu memediasi hubungan antara green image dengan green loyalty. Persepsi tamu tentang green image, green trust, dan green satisfaction dapat membantu meningkatkan green loyalty pada industri perhotelan khususnya di Hotel Bali Tropic Resort \& Spa. Isu lingkungan dalam konteks bisnis saat ini masuk ke dalam strategi dan kebijakan dari manajemen Hotel Bali Tropic Resort \& Spa, tidak hanya dalam membangun loyalitas pelanggan tetapi juga kepercayaan dan kepuasan pelanggan. Hotel Bali Tropic Resort \& Spa juga sudah membantu program pemerintah untuk menerapkan prinsip-prinsip ramah lingkungan, khususnya di bidang industri perhotelan, terbukti dari penghargaan yang sudah diperoleh.

Ruang lingkup penelitian ini hanya dilakukan di Hotel Bali Tropic Resort \& Spa, sehingga diharapkan pada penelitian selanjutnya dapat dapat dilakukan pada 
N.L.G. Sari Dewi Astuti, dan I Pt. Gede Sukaatmadja. Peran Green Trust dan Green .......

green hotel lainnya, untuk menggeneralisasi temuan di penelitian ini. Penelitian ini telah membahas hubungan antara variabel-variabel yang diminati, tanpa mempertimbangkan anteseden dan konsekuensi lainnya. Dengan demikian masih diperlukannya penelitian-penelitian untuk mengeksplorasi lebih jauh lagi mengenai variabel mediasi lainnya seperti komitmen mengenai masalah lingkungan.

\section{SIMPULAN DAN SARAN}

Green image memiliki hubungan positif dengan green trust. Semakin kuat green image yang ada pada Hotel Bali Tropic Resort \& Spa, maka semakin meningkat pula tingkat green trust dari tamu. Green image memiliki hubungan positif dengan green satisfaction. Semakin kuat green image dari Hotel Bali Tropic Resort \& Spa maka, semakin meningkat pula tingkat green satisfaction dari tamu. Green trust memiliki hubungan positif dengan green loyalty. Semakin tinggi green trust dari tamu selama mereka menginap di Hotel Bali Tropic Resort \& Spa, maka semakin meningkat pula tingkat green loyalty dari tamu. Green satisfaction memiliki hubungan positif dengan green loyalty. Semakin tinggi green satisfaction dari tamu selama mereka menginap di Hotel Bali Tropic Resort \& Spa, maka semakin meningkat pula tingkat green loyalty dari tamu. Green image memiliki hubungan positif dengan green loyalty. Semakin baik green image yang dimiliki oleh Hotel Bali Tropic Resort \& Spa, maka semakin meningkat pula tingkat green loyalty dari tamu. Peran mediasi green trust pada hubungan green image dengan green loyalty memberikan pengaruh yang positif dan signifikan terhadap tamu di Hotel Bali Tropic Resort \& Spa. Peran mediasi 
green satisfaction pada hubungan green image dengan green loyalty memberikan pengaruh positif dan signifikan terhadap tamu di Hotel Bali Tropic Resort \& Spa. Adanya kesediaan tamu akan memberikan ulasan yang baik dan merekomendasikan kepada keluarga dan teman untuk menginap di Hotel Bali Tropic Resort \& Spa dapat dimanfaatkan oleh pihak Hotel Bali Tropic Resort \& Spa dalam melakukan pemasaran dan mengenalkan hotel mereka agar tamu lain tertarik untuk mencoba menginap di Hotel Bali Tropic Resort \& Spa. Penelitian di masa akan datang perlu mempertimbangkan untuk menggunakan konstruk lain yaitu komitmen mengenai masalah lingkungan mediasi antara green image terhadap green loyalty. Peran green trust dan green satisfaction sebagai mediator antara green image dan green loyalty, diharapkan pada penelitian di masa depan perlu menggaris bawahi mengembangkan green trust dan green satisfaction. Penelitian di masa depan dapat memperluas melakukan penelitian pada perusahaan ataupun green hotel yang berbeda di daerah lain. 
N.L.G. Sari Dewi Astuti, dan I Pt. Gede Sukaatmadja. Peran Green Trust dan Green .......

\section{REFERENCE}

Astini, R. 2016. Implikasi Green Brand Image, Green Satisfaction, dan Green Trust terhadap Loyalitas Pelanggan (Studi Kasus pada Konsumen AMDK Galon Merk AQUA di Wilayah Serpong Utara). Jurnal Manajemen Pemasaran. Vol 20, No 01. pp. 19-34.

Bastian, D.A. 2014. Analisa Pengaruh Citra Merek (Brand Image) dan Kepercaraan Merek (Brand Trust) Terhadap Loyalitas merek (Brand Loyalty) ADES PT. Ades Alfindo Putra. Jurnal Manajemen Pemasaran. Vol. 2, No.1. pp.1-9.

Chan, W.W., and Ho, K. 2006. Hotel's Environmental Management Systems (ISO 14001): Creative Financing Strategy.International Journal of Contemporary Hospitality Management, Vol 18, No 4. pp. 302-316.

Chan, S.W. 2013a. Gap Analysis of Green Hotel Marketing.International Journal of Contemporary Hospitality Management, Vol 25, No 7. pp. 1017-1048.

Chang, N-J., \& Fong, C-M. 2010. Green Product Quality, Green Corporate Image, Green Customer Satisfaction, and Green Customer Loyalty. Journal of Business Management, Vol. 4, No.13. pp. 2836-2844.

Chen, Y.S. 2010. The Drivers of Green Brand Equity: Green Brand Image, Green Satisfaction and Green Trust.Journal of Business Ethics, Vol 93, No 2. pp. 307-319.

Chen, Y-S., Lin, C-Y., and Weng, C-S. 2015. The Influence of Environmental Friendliness On Green Trust: The Mediation Effects of Green Satisfaction and Green Perceived Quality. Journal of Open Access Sustainability, Vol 7. pp. 10135-10152

Efendy, P., dan Suryadinata Y.A. 2014. Analisa Pengaruh Brand Image dan Btand Trust Terhadap Brand Loyalty Di Restoran D'COST Surabaya. Journal HospitalityManagement, Vol. 3, No. 2. pp. 613-627.

Hayu, R. 2014. The Influence of Satisfaction, Trust And Price of Consumer Loyalty On Green Product. Management Insight, Vol 9, No 1. pp. 30-44.

Hsieh, Y.C. 2012. Hotel Companie's Environmental Policies and Practices: A Content Analysis of Their Web Pages.International Journal of Contemporary Hospitality Management, Vol24, No 1. pp. 97-121.

Hur, W.M., Kim, Y. and Park, K. 2013. Assessing The Effects of Perceived Value and Satisfaction on Customer Loyalty: A Green Perspective Corporate 
Social Responsibility andEnvironmental Management, Vol 20, No 3. pp. 146-156.

Kang, S. and Hur, W.H. 2012. Investigating The Antecedents of Green Brand Equity: A Sustainable Development Perspective.Corporate Social Responsibility and EnvironmentalManagement, Vol 19, No 5. pp. 306-316.

Lavidge, R.J. and Steiner, G.A. 1961. A Model For Predictive Measurements of Advertising Effectiveness.Journal of Marketing, Vol 25, No 6. pp. 59-62.

Martínez, P., Pérez, A. and Rodríguez del Bosque, I. 2014. Exploring The Role of CSR in The Organizational Identity of Hospitality Companies: A Case from The Spanish Tourism Industry.Journal of Business Ethics, Vol 121, No 1. pp. 47-66.

Martínez, P. and Rodríguez del Bosque, I. 2013. CSR and Customer Loyalty: The Roles of Trust, Customer Identification with The Company and Satisfaction.International Journal ofHospitality Management, Vol 35, No 1. pp. 89-99.

Martinez, P. 2015. Customer Loyalty : Exploring it's Antecedents From a Green Marketing Perspective, International Journal ofHospitality Management Vol 27, No5. pp.896-917.

Muji, 2008. Pengaruh Relationship Marketing terhadap Kepuasan dan Loyalitas Pelanggan Kartu Kredit Visa BNI'46 Surabaya. Journal of Management, Vol 15, No. 6. pp. 1-25.

Nirmala dan Sukma. 2015. Trust dan Satisfaction Sebagai Variabel Mediasi Pengaruh Service Quality dan Product Quality pada Loyalitas Konsumen. Journal of Business Management, Vol. 5, No. 1. pp 1-11.

Ouyang, Y. 2010. A Relationship between Financial Consultant's Service Quality and Customer Trust After Financial Tsunami.International Research Journal of Finance And Economics, Vol 10, No 2. pp. 161-70.

Pianroj. 2012. Perceived Customer Loyalty Toward Green Hotels: A Study of International Tourists in the South of Thailand. Journal of Management, Vol.10, No.2. pp 40-50.

Polo, A.I., Frías, D.M. and Rodríguez, M.A. 2013. Antecedents of Loyalty Toward Rural Hospitality Enterprises: The Moderating Effect of The Customer's Previous Experience. InternationalJournal of Hospitality Management, Vol 34, No 1. pp. 127-137.

Pramudyo, A. 2012. Pengaruh Citra Merek Terhadap Loyalitas Melalui Kepuasan 
N.L.G. Sari Dewi Astuti, dan I Pt. Gede Sukaatmadja. Peran Green Trust dan Green .......

Sebagai Intervening (Studi Pada Mahasiswa Perguruan Tinggi Swasta di Yogyakarta). JBMA. Vol.1, No.1. pp 1-16.

Raditya, Hermanto, dan Ilhamuddin. 2015. Pengaruh Green Product Quality dan Green Perceived Risk terhadap Green Customer Satisfaction serta Green Customer Loyalty pada konsumen pertamax/pertamax plus di Kota Mataram. Journal of Management, Vol 44, No 2. pp. 1-17.

Ramadhan, 2010. Analisis Antesenden Green Brand Equity Hubungannya dengan Customer Loyalty. Journal of Management, Vol 35, No. 3. pp. 1-20.

Raza, A and Zia, R. 2012. Impact Of Relationship Marketing Tactics on Relationship Quality and Customer Loyalty : A Case Study of Telecom Sector of Pakistan.African Journal of Business Management, Vol 6, No14. pp.5085-5092.

Saleem, M. A., Khan, M. A., \& Alam, S.2015. Antecedents of Green Purchase Intentions: Evidence From Customers of Electronics Products From Multan District. Journal of European Academic Research, (II). pp. 14900-14916.

Siwandana, I.K.L, dan Wardana, I.M.2017. Peran Green Trust Memediasi Pengaruh Green Brand Image Terhadap Green Brand Equity Pada Produk Hijau, Journal of Management, Vol 6,No 4. Hal. 1789-1815.

Susanti N.P.H, dan Wardana, I.M. 2014. Pengaruh Kualitas Produk dan Citra Merek Terhadap Kepuasan dan Loyalitas Pelanggan pada Produk Kosmetik Hijau Merek The Body Shop. Journal of Management, Vol. 4 No. 2, pp. 622-636.

Wenur, Silvya, dan Tumbuan. 2015. Pengaruh Strategi Green Marketing, Citra Merek, dan Kualitas Produk Terhadap Kepuasan Konsumen Pengguna The Body Shop, Manado Town Square. Journal of Management, Vol 3, No 2. Hal. 283-293.

Wiyono. 2015.Pengaruh Green Brand Image, Green Satisfaction, dan Green Trust Terhadap Green Brand EquityMerek Lg Di Surabaya, Journal of Management, Vol 4,No2 pp. 1-17.

Yi Kuo, Hi.2012. Modelling The Influence of Green Brand Image on Brand Loyalty in Technology Products: Brand Identification, Perceived Value and Brand Loyalty.Journal of Management, Vol, 42, No. 7. pp. 121-135 